\title{
Markers of angiogenesis in ovarian cancer
}

\author{
William M. Merritt ${ }^{\mathrm{a}}$ and Anil K. Sood ${ }^{\mathrm{a}, \mathrm{b}, *}$ \\ ${ }^{a}$ Department of Gynecologic Oncology, U.T. M.D. Anderson Cancer Center, Unit 1362, P.O. Box 301439, Houston \\ TX 77230-1439, USA \\ ${ }^{\mathrm{b}}$ Department of Cancer Biology, U.T. M.D. Anderson Cancer Center, 1515 Holcombe Boulevard, Unit 173, \\ Houston TX 77030, USA
}

\begin{abstract}
Tumor development and progression are inherently dependent on the process of angiogenesis. Recently, anti-angiogenic therapy has started to show promise as an effective treatment strategy in many solid tumors including ovarian carcinoma. Unfortunately, lack of effective biomarkers presents a challenge for oncologists in treatment planning as well as monitoring response of new anti-vascular agents. Previously, quantification of angiogenesis by microvessel density analysis provided useful prognostic information, however, its utility following anti-angiogenic therapy remains to be determined. Moreover, since secreted cytokines play an active part in angiogenesis by mediating neovascularization in tumors, investigations have focused on their potential role to serve as candidate biomarkers of disease detection, prognosis, and treatment response. In this article, we review the role of key angiogenesis markers as potential biomarkers in ovarian carcinoma.
\end{abstract}

Keywords: Angiogenesis, biomarker, ovarian carcinoma, therapy

\section{Introduction}

Tumor growth and metastasis are inherently dependent on the development of a blood supply or neovascularization. Angiogenic processes must be activated for tumor growth beyond $1 \mathrm{~mm}$ [33]. These processes include a shift in balance toward greater levels of pro-angiogenic compared to anti-angiogenic factors (Table 1). During angiogenesis, tumors utilize the host's cellular machinery to develop an adequate vascular supply which is dependent upon the presence of activated endothelial cells. Multiple angiogenic activators play a role in initiating endothelial cell proliferation, migration, and survival $[32,69,86,87]$. Collectively, these components lead to the formation of new vascular channels which deliver oxygen and nutrients to the tumor beds.

The functional and architectural characteristics of tumor blood vessels are quite different in comparison to

\footnotetext{
*Corresponding author: Anil K. Sood, M.D., Professor, Departments of Gynecologic Oncology and Cancer Biology, The University of Texas M.D. Anderson Cancer Center, Unit 1362, P.O. Box 301439, Houston TX 77230-1439, USA. Tel.: +1 713745 5266; Fax: +1 713 792 7586; E-mail: asood@mdanderson.org.
}

normal vessels. For example, tumor vessels are tortuous, highly permeable and irregularly shaped compared to normal vasculature [14]. The formation of tumor blood vessels is complex and likely involves multiple pathways. Angiogenesis can occur from "sprouting" or intussusceptive growth from pre-existing vessels $[19,100]$. Non-sprouting angiogenesis results from enlargement, splitting and fusion of pre-existing vessels. There is growing evidence that the initial events in tumor vascularization likely involve cooption of existing vessels by tumor cells [49] followed by production of factors such as Angiopoietin-2 that destabilize the host vasculature resulting in central tumor necrosis. In this setting, angiogenesis occurs secondarily in the tumor periphery as a result of increased production of angiogenic factors. Additional mechanisms of tumor neovascularization include vasculogenesis, which is the formation of new blood vessels from precursor mesodermal cells mobilized from the bone marrow [76, 97]. Hendrix and colleagues have described the plasticity of tumor cells whereby aggressive tumor cells adopt molecular features that are similar to endothelial cells (i.e., vasculogenic mimicry) [79,105-107]. This intriguing pathway suggests that aggressive tumor cells 
Table 1

Regulators of angiogenesis

\begin{tabular}{ll}
\hline Activators & Inhibitors \\
\hline Vascular endothelial growth factor (VEGF) & Thrombospondin \\
Fibroblast growth factor, acidic and basic (FGF) & Angiostatin \\
Transforming growth factor-beta (TGF- $\beta$ ) & Endostatin \\
Epidermal growth factor (EGF) & N-terminal prolactin fragments \\
Platelet derived growth factor (PDGF) & Interferon-alpha (INF- $\alpha$ ) \\
Tumor necrosis factor- alpha (TNF- $\alpha$ ) & Interleukin-12 (IL-12) \\
Interleukin-8 (IL-8) & Vasostatin \\
Interleukin-6 (IL-6) & Growth hormone \\
Angiopoietin 1,2 (Ang1, Ang2) & Dopamine \\
Cyclooxygenase-2 (COX-2) & \\
Catecholamines & \\
Hypoxia inducible factor-1-alpha (HIF-1 $\alpha$ ) & \\
Matrix metalloproteinases (MMPs) & \\
Ephrins/ Eph receptors & \\
Prolactin (PRL) & \\
Angiogenin & \\
\hline
\end{tabular}

may have the ability to directly participate in the development of tumor vasculature.

Anti-angiogenic approaches are starting to show promise in pre-clinical and clinical investigations across multiple tumor types including ovarian carcinoma [18,54]. Bevacizumab was the first anti-vascular agent to receive approval from the Food \& Drug Administration (FDA) for clinical use when given in combination with chemotherapy based on results from a phase III trial showing a 4.7 month improvement in overall survival in previously untreated, metastatic colorectal cancer patients [52]. We have previously reported the benefits of developing agents that target specific components of the vascular system and their potential role in ovarian cancer therapy [58]. Furthermore, we have shown in pre-clinical models that targeting genes responsible for angiogenesis with novel therapeutic strategies, such as siRNA targeted therapy, has therapeutic efficacy and these approaches are being developed clinically $[65,66]$. Traditional biomarkers may not be optimal for following patients on antiangiogenic therapies. Based on the growing portfolio of anti-angiogenic approaches and the role of angiogenesis in affecting the course of malignant disease, we will review the predictive and prognostic relevance of tumor neovascularization and associated biomarkers in ovarian carcinoma.

\section{Quantitative angiogenesis}

To the extent that angiogenesis is related to tumor growth, it was hypothesized that quantification of angiogenesis may be useful as a predictive factor. Initial studies focused on assessing the density of blood vessels (MVD) as a marker for angiogenesis in human tumors $[16,74,118]$. This method utilizes immunohistochemical (IHC) staining of endothelial-specific markers such as CD34, CD31, or factor VIII-related antigen. The number of blood vessels is then counted in multiple regions of the tumor as a measure of angiogenesis.

Increased vascularity and MVD are poor prognostic factors in most human malignancies [96]. Specifically in ovarian carcinoma, several studies have examined the utility of MVD as a prognostic factor [4,73, 108]. Hollingsworth and colleagues were one of the first investigators that utilized CD34 staining and found an inverse relationship between MVD counts and both disease free and overall survival [50]. In contrast, Abulafia reported no correlation between overall survival and MVD analysis in primary ovarian tumors, however MVD of omental metastases from 19 patients was an independent prognostic factor for patient survival [2]. More recently, larger studies have shown not only an inverse relationship between MVD and overall patient survival, but also that increased vascularity related to higher stage, higher grade, and the lower likelihood of optimal tumor reductive surgery [4,108]. Table 2 summarizes these and additional studies correlating MVD in patients with ovarian carcinoma. Collectively, these results suggest that MVD may be a clinically useful application for prognosis and assist in treatment planning, especially in patients with low-stage ovarian cancer.

In pre-clinical studies, MVD analysis has been an effective tool to assess the effects of investigational drugs and treatment regimens in animal models [65]. IHC staining of endothelial markers allows investigators to analyze the angiogenic effects in tumors fol- 
Table 2

Summary of tumor MVD analyses in patients with ovarian carcinoma

\begin{tabular}{|c|c|c|c|c|}
\hline Author & Year & Number of Patients & Method & Associated Outcome \\
\hline Hollingsworth et al. [50] & 1995 & 45 & IHC-CD34 & OS and DFS \\
\hline Abulafia et al. [2] & 1997 & $\begin{array}{l}49 \text { (primary) } 19 \text { (omental } \\
\text { metastases) }\end{array}$ & IHC - factor VIII related antigen & $\begin{array}{l}\text { OS (only in MVD analysis in omen- } \\
\text { tal metastases) }\end{array}$ \\
\hline Alvarez et al. [4] & 1999 & 87 & IHC-vWF \& CD31 & OS and stage \\
\hline Heimburg et al. [46] & 1999 & 38 & IHC-CD34 & OS \\
\hline Obermair et al. [90] & 1999 & 63 & IHC-CD34 & OS \\
\hline Stone et al. [108] & 2003 & 202 & IHC-CD31 & $\begin{array}{l}\text { OS, stage, grade, and potential for } \\
\text { level of cytoreduction }\end{array}$ \\
\hline Chan et al. [21] & 2004 & 46 & IHC-CD34 & Age and OS \\
\hline Raspollini et al. [98] & 2005 & 33 & $\mathrm{IHC}-\mathrm{CD} 34 *$ & OS and response to therapy \\
\hline Karavasilis et al. [59] & 2006 & 33 & IHC-CD34 & No association \\
\hline Lin et al. [73] & 2006 & 77 & $\mathrm{IHC}-\mathrm{CD} 31$ & $\begin{array}{l}\text { Stage, ascites, potential for level of } \\
\text { cytoreduction }\end{array}$ \\
\hline
\end{tabular}

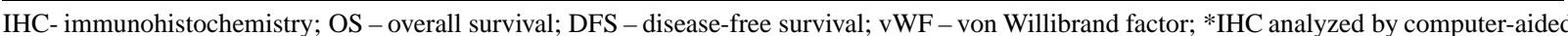
imaging.

lowing treatment with new agents. For example, antivascular therapy targeting vascular endothelial growth factor (VEGF) and epidermal growth factor (EGF) receptors resulted in decreased tumor growth in ovarian cancer models [112]. In this study, CD31 staining was used to demonstrate that therapy reduced tumor vasculature by inducing apoptosis of tumor-associated endothelial cells [112]. However, the applicability of MVD analysis in the clinical setting remains to be determined. Investigators are challenged with the difficulty in obtaining multiple tissue biopsies, especially in patients with recurrent disease, to correlate known prognostic factors as well as therapeutic response with MVD assessment. In addition, inherent difficulties in MVD analysis including observer subjectivity and length of time required for manual counting need to be addressed. Recently, Schoell and colleagues used computer-aided image analysis to overcome some of these limitations and reported a clinical value of MVD analysis as a useful prognostic factor for patients with ovarian cancer [102]. As new anti-angiogenic therapies become available, further studies will be needed to validate the utility of MVD analysis in treatment planning and response in patients with ovarian cancer.

\section{Secreted growth factors/cytokines}

\subsection{Vascular endothelial growth factor}

Endogenous growth factors are widely known for their importance in angiogenesis. In normal tissues, secretion of growth factors is tightly regulated and increases transiently in specific processes such as wound healing and menstrual cycle regulation $[10,38,120]$.
However, there is a sustained increase in growth factor levels in tumors resulting in progressive neovascularization and tumor growth. One of the more prominent angiogenic mediators for new vessel growth in tumors is vascular endothelial growth factor (VEGF), also known as vascular permeability factor (VPF). VEGF overexpression results in increased endothelial cell proliferation, capillary tube formation, and vascular permeability [81,123]. Moreover, VEGF is an important survival factor for endothelial cells [36]. For these reasons, VEGF may be both a potential biomarker as well as a target for therapy. Indeed, VEGF targeted therapy has demonstrated promising results as one of the first clinically available anti-angiogenic agents in cancer therapy $[52,54]$.

The VEGF gene encodes for several members, but VEGFA (commonly noted as VEGF) appears to play a dominant role in angiogenesis. There are four different isoforms of VEGF that occur in humans through alternative RNA splicing: $\mathrm{VEGF}_{121}, \mathrm{VEGF}_{165}, \mathrm{VEGF}_{189}$, and $\mathrm{VEGF}_{206}$. The release of VEGF by normal and tumor cells is controlled by several mechanisms. VEGF secretion, in addition to other growth factors including EGF, platelet derived growth factor (PDGF), transforming growth factor alpha and beta (TGF $\alpha \& \beta)$, and fibroblast growth factor (FGF), are upregulated by stressful conditions, such as hypoxia, a common finding in solid tumors [30]. The presence of the Ras oncogene [40] and tumors with mutations of the p53 tumor suppressor gene [122] also result in overexpression of VEGF. Lastly, inflammatory cytokines, such as interleukin-1 (IL-1) and interleukin-6 (IL-6), released by tumor cells and the host's immune system stimulate growth factor secretion [84]. In normal tissue, inactivation of VEGF is mediated by the von Hippel Lindau 
(VHL) gene [29], however this negative feedback process is generally overwhelmed in tumor neovascularization.

VEGF has multiple effects on endothelial cells through ligand binding to the VEGFR family of receptors: VEGFR-1, 2, and 3. This receptor activation in turn initiates a cascade of events including activation of members of the mitogen activated protein kinase (MAPK) pathway and phosphatidylinositol kinase (PI3K), which are important events for endothelial cell survival [30,36,47]. VEGFR-1 and 2 are important not only in tumor angiogenesis but also embryonic development. For example, mice lacking VEGF and its receptors die in utero due to lack of adequate vascular development $[20,104]$. Each receptor within the VEGFR family has been classified based on its function following activation by ligand binding. VEGFR-1 mobilizes endothelial progenitor cells in addition to stimulating the release of proteolytic factors such as matrix metalloproteinase-9 (MMP-9) [45,48]. In addition, a soluble form of VEGFR-1 has been discovered and is known to have anti-angiogenic activity when bound to circulating VEGF [62]. VEGFR-2 is predominantly the receptor responsible for neovascularization. With the association of "ligand chaperones" (neuropilin 1 and 2), VEGF binds to VEGFR-2 with high affinity and in turn stimulates increased endothelial cell proliferation, migration, and survival [30]. VEGFR-3 binds to other members of the VEGF gene family, VEGFC and VEGFD. VEGFR-3 activation has been shown to play a role in lymphangiogenesis and remains a new area for metastatic research [60].

VEGF overexpression is reported in multiple solid tumors including breast, ovary, colon, lung, and uterine cancers $[25,27,67,103,113]$. For this reason, multiple investigations have focused on utilizing measurements of circulating VEGF as a potential marker for ovarian cancer patients (Table 3) [96]. In several large studies, serum VEGF was significantly elevated pre-operatively in patients with malignant ovarian disease $[22,23,71$, 89]. In addition, one study reported only $40 \%$ of patients with low stage disease had VEGF overexpression [93]. Since growth factor expression appears to be related to disease burden, early stage disease may not be a formidable setting to depend on angiogenesis as a screening tool. However, since only $70-80 \%$ of ovarian carcinomas secrete CA-125, serum VEGF measurements may be a promising marker of disease presence in a subset of patients with ovarian carcinoma [101].

The overexpression of VEGF in patients with advanced stage disease may provide useful information as a prognostic factor for oncologists. In patients with ovarian cancer, VEGF overexpression correlated with advanced stage disease, ascites, and decreased overall survival [22,114]. Furthermore, Oehler and colleagues reported that serum VEGF levels significantly decreased following cytoreductive surgery and were also decreased in patients with low residual disease [91]. However, in multivariate analysis, they indicated that serum VEGF levels were not predictive of patient survival [91]. Moreover, Alvarez and colleagues reported that serum VEGF levels were not predictive of disease recurrence in a small subset of patients with a positive second look surgery [5]. Interestingly, when combined with MVD analyses or cyclooxygenase-2 (COX2) expression, VEGF expression was predictive of disease free interval and chemotherapy response $[99,121]$. Based on these findings, quantifying different combinations of angiogenic factors, including VEGF, could assist in deciding which patients may benefit from more aggressive adjuvant treatment regimens.

Growth factors have become highly attractive targets for anti-angiogenic therapy. Pre-clinical research has demonstrated that inhibition of specific growth factors can effectively reduce tumor growth of human ovarian cell lines in murine models when used alone and in combination with chemotherapy $[6,17,112]$. Currently there are no effective surrogate markers for antivascular therapy. Bevacizumab, a humanized monoclonal antibody against VEGF, is one of the few approved anti-angiogenic therapeutic agents for cancer therapy and is currently being studied in ovarian cancer clinical trials (Fig. 1). Previously, bevacizumab therapy has shown benefit in patient survival in phase III colorectal and breast trials [54]. In these studies, plasma VEGF levels actually increased thereby questioning the value of VEGF as a surrogate marker following anti-VEGF therapy [54,119].

Anti-angiogenic agents that target VEGF activity via receptor inhibition may also help investigators identify new potential biomarkers in cancer therapy. Recently, Ebos and colleagues identified a soluble form of VEGFR-2 (sVEGFR-2) that binds to VEGF [26]. Measurable levels of sVEGFR-2 were found in the plasma of both mice and humans [26]. While it was proposed that ligand binding to sVEGFR-2 may result in antiangiogenic activity, as seen with the soluble form of VEGFR-1, the actual biological role has not been elucidated. Based on these data, Motzer and colleagues investigated the benefit of using sVEGFR-2 as a biomarker in a recent phase I trial [83]. In that study, patients with metastatic renal cell carcinoma were treated with 
Table 3

Summary of VEGF measurements for disease detection in patients with ovarian carcinoma

\begin{tabular}{|c|c|c|c|c|c|c|}
\hline Author & Year & $\begin{array}{l}\text { Study } \\
\text { size }\end{array}$ & Sample & $\begin{array}{l}\text { Sensitivity } \\
(\%)\end{array}$ & $\begin{array}{l}\text { Specificity } \\
(\%)\end{array}$ & Comments \\
\hline Obermair A, et al. [89] & 1998 & $\begin{array}{l}\text { C: } 131 \\
\text { B: } 81 \\
\text { M: } 44\end{array}$ & sVEGF & 54 & 77 & $\begin{array}{l}\text { No difference in sVEGF levels among all } \\
\text { groups }\end{array}$ \\
\hline Oehler MK, et al. [92] & 1999 & $\begin{array}{l}\text { C: } 20 \\
\text { B: } 20 \\
\text { M: } 41\end{array}$ & sVEGF & 71 & 65 & $\begin{array}{l}\text { sVEGF levels significantly higher from pa- } \\
\text { tients with malignancies versus control and } \\
\text { benign groups }\end{array}$ \\
\hline Cooper BC, et al. [22] & 2002 & $\begin{array}{l}\text { B: } 34 \\
\text { L: } 16 \\
\text { M: } 101\end{array}$ & sVEGF & 74 & 71 & $\begin{array}{l}\text { sVEGF levels significantly higher from pa- } \\
\text { tients with malignancies versus benign or } \\
\text { LMP groups } \\
\text { No difference in sVEGF levels between LMP } \\
\text { and benign groups }\end{array}$ \\
\hline Dehaven K, et al. [23] & 2002 & $\begin{array}{l}\text { C: } 125 \\
\text { B: } 71 \\
\text { M: } 46\end{array}$ & sVEGF & N/A & N/A & $\begin{array}{l}\text { No difference in sVEGF levels among all } \\
\text { study groups }\end{array}$ \\
\hline Tanir HM, et al. [110] & 2003 & $\begin{array}{l}\text { B: } 50 \\
\text { M: } 12\end{array}$ & sVEGF & 92 & 88 & $\begin{array}{l}\text { sVEGF levels significantly higher in patients } \\
\text { with malignant tumors }\end{array}$ \\
\hline Demirkiran F, et al. [24] & 2003 & $\begin{array}{l}\text { B: } 45 \\
\text { M: } 43\end{array}$ & $\begin{array}{l}\text { sVEGF } \\
\text { cVEGF }\end{array}$ & 95 & 78 & $\begin{array}{l}\text { sVEGF and cVEGF significantly elevated in } \\
\text { patients with malignant tumors }\end{array}$ \\
\hline Harlozinska A, et al. [44] & 2004 & $\begin{array}{l}\text { B: } 53 \\
\text { M: } 86\end{array}$ & $\begin{array}{l}\text { sVEGF } \\
\text { cVEGF }\end{array}$ & N/A & N/A & $\begin{array}{l}\text { sVEGF and cVEGF significantly elevated in } \\
\text { patients with malignant tumors }\end{array}$ \\
\hline Li L, et al. [71] & 2004 & $\begin{array}{l}\text { C: } 90 \\
\text { B: } 25 \\
\text { M: } 120\end{array}$ & sVEGF & 77 & 87 & $\begin{array}{l}\text { sVEGF levels significantly higher from pa- } \\
\text { tients with malignancies versus control and } \\
\text { benign groups. } \\
\text { Increased sVEGF levels were significant in } \\
\text { patients with distant metastases }\end{array}$ \\
\hline Gorelik E, et al. [39] & 2005 & $\begin{array}{l}\text { C: } 45 \\
\text { B: } 37 \\
\text { M: } 44\end{array}$ & $\begin{array}{l}\text { sVEGF, } \\
\text { IL-8, IL-6, } \\
\text { CA-125, } \\
\text { sEGF }\end{array}$ & 84 & 95 & $\begin{array}{l}\text { Significant elevation in serum cytokine levels } \\
\text { from patients with malignant tumors versus } \\
\text { control and benign groups }\end{array}$ \\
\hline
\end{tabular}

sVEGF- serum vascular endothelial growth factor; cVEGF- cystic vascular endothelial growth factor; C- healthy control patients; B- benign ovarian neoplasms; M- malignant ovarian carcinoma; L- low malignant potential ovarian neoplasms; IL-8 - interleukin 8; IL-6 - interleukin 6; sEGF - serum epidermal growth factor; N/A - not available.

single agent therapy using a small molecule inhibitor of VEGF and PDGF receptors, SU11248 [83]. Interestingly, they reported a decrease in plasma sVEGFR-2 levels following therapy while VEGF levels increased. The latter finding is consistent with previous reports of sVEGFR-2 modulation following anti-VEGF therapy, however, the mechanism by which SU11248 affects sVEGFR-2 is not fully known.

As investigators begin to understand the molecular pathways involved in tumor angiogenesis, new agents are being developed that target upstream regulators of VEGF expression (Fig. 1). For example, Src, a nonreceptor tyrosine kinase, has been reported to mediate angiogenesis by upregulating pro-angiogenic factors such as VEGF and interleukin-8 (IL-8) [109]. Recently, we have demonstrated in ovarian cancer models that Src inhibition decreased tumor growth and significantly decreased serum VEGF and IL-8 levels. Similarly, siRNA based therapy against FAK, a non-receptor kinase known to regulate VEGF, reduced circulating VEGF levels in response to treatment [41]. These find- ings suggest a unique opportunity to further explore the role of VEGF as a surrogate marker of response to new agents that mediate angiogenic activity.

Development and validation of circulating VEGF levels as a biomarker may also depend on the type of study design and sample collection obtained by investigators. For example, VEGF levels can differ among serum and plasma samples taken from the same patient [3]. This is partly due to the secretion of VEGF from components of the circulatory system including platelets, neutrophils, monocytes, and lymphocytes $[34,116]$. In addition, anti-coagulants often found in blood collection tubes can falsely elevate VEGF levels due to platelet-derived secretion in non-clotted samples [117]. The significance of platelet-derived VEGF remains controversial due to suggestions that platelets may mediate release of angiogenic molecules in the presence of tumor cells and therefore reflect the true disease process [31,94]. Although, these differences in circulating levels have been demonstrated in several studies from patients with malignant disease [3] 


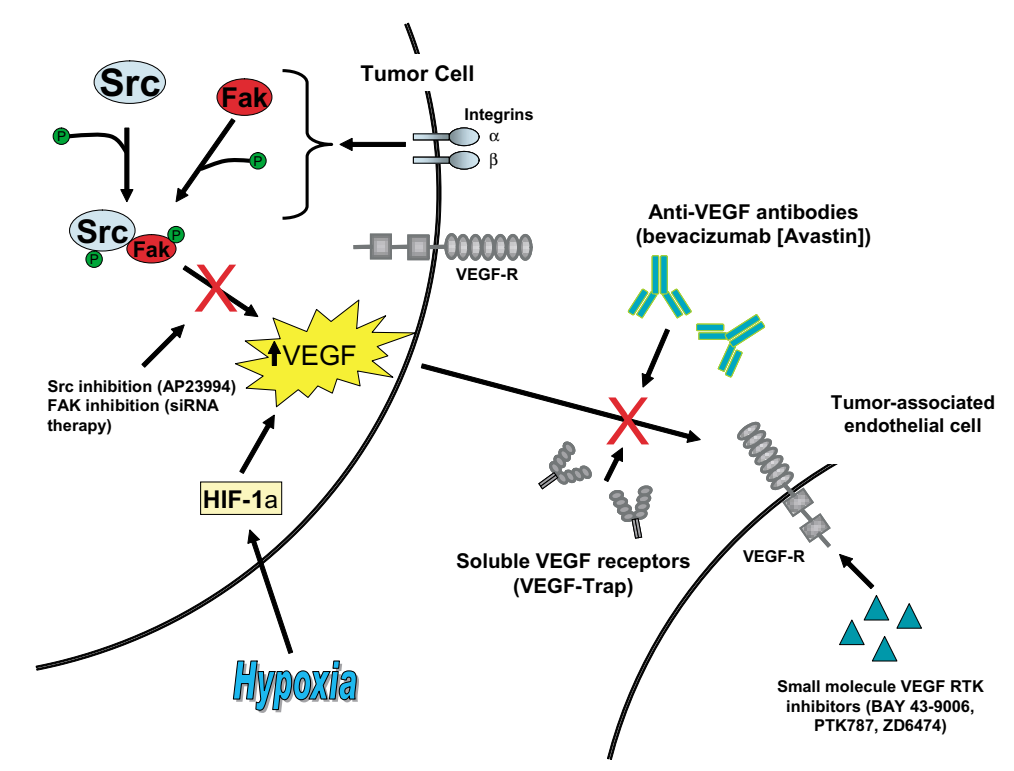

Fig. 1. VEGF secreted from tumor cells binds to tumor-associated endothelial cells leading to increased neovascularization and permeability. Different therapeutic agents are capable of decreasing VEGF expression (Src or FAK inhibition) or preventing ligand binding to the VEGF receptor (anti-VEGF antibodies or soluble VEGF receptors). In addition, small molecule inhibitors inhibit receptor tyrosine kinase (RTK) activity of VEGF receptors, thereby preventing angiogenic activity of endothelial cells.

larger prospective studies will be required to determine the appropriate assay and levels to utilize for clinical consideration.

\subsection{Interleukin-8}

Interleukins are important members of the cytokine family and are known to modulate normal defense systems in the human body. Stressful environments, such as hypoxia and surgical stress, activate release of interleukins from inflammatory cells, peritoneal mesothelial cells, fibroblasts, and endothelial cells into the systemic circulation and in turn initiate protective pathways [63]. Ovarian carcinoma, once labeled a "cytokine propelled disease", secretes large amounts of interleukins into circulation, which in turn mediate tumor growth, metastasis, and angiogenesis [77]. Moreover, increased circulating levels of interleukins have been demonstrated in several malignancies including ovarian carcinoma and are associated with poor patient survival $[61,75]$. For these reasons, interleukins involved in angiogenesis remain of particular interest as biomarkers in ovarian carcinoma.

Interleukin-8 is well known for its role in tumor invasion, metastatic spread, and angiogenesis. IL-8 is a small $(8 \mathrm{kDa})$ chemotactic cytokine that belongs to the CXC cytokine family known for activating and attracting neutrophils [53]. IL-8 binds to the seven- transmembrane spanning G-protein coupled receptors CXCR1 and CXCR2 with high affinity and in turn activates members of the MAPK kinase pathway including ERK 1/2 [72]. IL-8 was initially reported as a prominent mediator of angiogenesis by Koch and colleagues in 1992 [64]. They demonstrated that recombinant IL-8 induced neovascularization in a rat corneal model [64]. Subsequently, Li and colleagues demonstrated the direct effect of IL-8 on human endothelial cell migration, capillary tube formation and survival $[69,70]$.

IL-8 is secreted by multiple sources including monocytes, neutrophils and mesothelial cells. Tumor cells also secrete IL-8, which in turn can act as an autocrine inducer of tumor growth or paracrine modulator of host endothelial cells in angiogenesis. In several small studies, IL-8 levels were elevated in the serum and ovarian cystic fluid in patients with ovarian carcinoma $[28,53$, 75,88]. Furthermore, Lokshin and colleagues demonstrated that IL-8 and anti-IL-8 antibody levels were increased in ovarian cancer patients and more specifically, that anti-IL-8 antibody levels correlated with early stage disease [75]. In addition, they reported a specificity of $98 \%$ for both IL- 8 and anti-IL- 8 antibody levels and sensitivities of $63 \%$ and $66 \%$, respectively, in disease detection [75]. Furthermore, the specificity and sensitivity increased to $98 \%$ and $88 \%$, respectively in combination with CA-125 [75]. To this end, IL-8 and anti-IL-8 antibodies may be possible screen- 
ing biomarkers for patients with ovarian tumors, especially when combined with traditional applications and markers such as pelvic ultrasound and CA-125.

Due to the role of IL- 8 in mediating tumor angiogenesis, quantifying circulating IL-8 levels may assist oncologists in treatment surveillance as a biomarker of response. In most circumstances, ovarian cancer patients are treated with platinum and taxane chemotherapy following cytoreductive surgery. Mayerhofer and colleagues reported that IL-8 levels decreased with chemotherapy in 31 patients [80]. In their study, IL-8 levels demonstrated a decreasing trend midway and following six cycles of combination chemotherapy [80]. Conversely, Uslu reported that IL-8 levels actually increased immediately following the initiation of chemotherapy in ovarian cancer patients, specifically in those with residual disease [115]. However, it has been shown that chemotherapy can transiently induce IL-8 secretion from tumor cells [68] and therefore may explain the differences in these two studies, especially those patients with residual disease.

Although anti-VEGF targeted therapy has demonstrated improvement in patient survival, few studies have reported the benefit of targeting IL- 8 in cancer therapy. In pre-clinical murine models, Bar-Eli and colleagues demonstrated that therapy with fully humanized anti-IL-8 antibodies decreased tumor growth and MVD [51]. To the best of our knowledge, no studies report the use of IL- 8 as an anti-vascular target in ovarian cancer. However, we recently demonstrated in pre-clinical models that circulating IL- 8 levels decreased secondary to Src inhibition [42] suggesting that IL-8 may be a useful marker for response to specific therapies. Clearly, with the emergence of new small molecule inhibitors and now effective applications for delivering gene-specific siRNA in vivo [65], IL-8 may be an attractive target for patients with ovarian carcinoma.

\subsection{Interleukin-6}

IL-6 was originally reported as a mediator in B cell maturation. Recently, Nilson and colleagues demonstrated that IL-6 mediated tumor growth and angiogenesis in ovarian cancer models [85]. In that study, IL-6 receptors were detected on ovarian and endothelial cells and were found to actively participate in the development of tumor angiogenesis [85]. Since IL-6 is secreted into circulation, it was suggested that IL-6 may be a potential marker for disease detection and surveillance in patients with ovarian tumors. Berek and colleagues were the first to report elevated serum IL-6 levels in ovarian cancer patients [13]. They found a direct correlation with IL-6 overexpression and decreased overall survival, increased tumor burden, and disease status [13]. In a study of 73 ovarian cancer patients, Tempfer and colleagues reported that increased IL-6 levels prior to therapy correlated with both decreased disease free and overall survival [111]. However, these findings have not been consistent in the literature [95]. In a more recent study, IL-6 demonstrated no added benefit as a disease biomarker when compared to traditional markers; however, when evaluated within a panel of cytokines, IL-6 was considered useful for disease detection [39]. To date, the benefit of measuring IL-6 as a marker of angiogenesis remains to be determined in ovarian cancer.

\section{Circulating endothelial cells}

The development of new vasculature requires activation and migration of endothelial cells. In most normal tissues, endothelial cells remain quiescent and divide approximately every 3-5 years. However, rapid proliferation of endothelial cells is crucial for the process of angiogenesis in growing tumors. As new vasculature matures, often endothelial cells can become dislodged into the systemic circulation. Recent studies have shown that levels of circulating endothelial cells (CEC) are elevated in cancer patients 3.6-5 fold compared to healthy controls and may be a reflection of ongoing angiogenesis $[12,35,78]$. In addition, tumorderived VEGF has also been shown to mobilize CECs in murine models and in humans $[9,11,55,56]$. Based on these findings, monitoring CEC levels may provide useful information regarding disease status and treatment efficacy in cancer patients.

Within the systemic circulation, two populations of CECs have been identified. Mature endothelial cells (CEC) are thought to derive from mature vasculature and circulating endothelial progenitor cells (CEP) are mobilized from the bone marrow. CEPs may contribute to the angiogenic process by differentiating into mature endothelial cells, however, their direct role has yet to be determined [7,8]. CECs and CEPs can be identified based on their expression of specific endothelial antigens using flow cytometry [11]. This distinction is critical for determining the effects of CECs and CEPs in response to current cancer treatments. For example, Beaudry and colleagues demonstrated in a murine model that CECs increased in response to ZD6474 (VEG- 
FR inhibitor), although CEPs decreased due to the inhibition of VEGF induced mobilization from the bone marrow [11].

CEC and CEP levels may be particularly useful for following response to anti-angiogenic therapy. Preclinical models have demonstrated that CEPs increase following treatment with cyclophosphamide, however treatment with endostatin (an inhibitor of angiogenesis) correlated with an increase in CECs [15,82]. Moreover, following treatment with anti-vascular agents, CEC and CEP levels have been reflective of vascular changes within the tumor and may provide more useful information in treatment response [11]. In support of this theory and based on the growing evidence that the frequency of chemotherapy administration may have antiangiogenic effects [37,43], we demonstrated a decrease in CEPs using metronomic chemotherapy scheduling, however CEC levels remained unchanged from baseline $[15,57]$. Moreover, anti-vascular therapy in combination with metronomic chemotherapy demonstrated a 79\% decrease in CEP levels [57]. While pre-clinical models of ovarian cancer have demonstrated that CEP and CEP levels may be beneficial as a surrogate marker to anti-vascular therapy [57] little is known about their role in patients with ovarian carcinoma. Only a few studies have followed CEC levels in patients with malignancies. For example, in breast and lymphoma patients, CEC levels were initially increased and correlated with tumor burden, however, upon remission became normalized [35,78]. As newer anti-vascular agents become available, quantifying CEC and CEP levels may be helpful in monitoring tumor growth and treatment response in patients with ovarian carcinoma.

\section{Concluding remarks}

Ovarian cancer remains the most deadly disease in women among gynecologic malignancies [1]. The majority of these patients initially respond to surgical debulking and chemotherapeutic regimens, but most eventually develop recurrent cancer and die from this disease. One of the difficulties in managing ovarian cancer patients is the lack of an effective biomarker for disease detection. Moreover, with the emergence of new anti-vascular therapies in ovarian cancer, there is a need for novel biomarkers for treatment response in patients. It is hoped that global analysis with gene microarrays may identify potential candidates to test as screening markers, therapeutic targets, and/or surrogate biomarkers of treatment response. Furthermore, new treatment approaches have allowed investigators to focus on specific targets that not only demonstrate anti-tumor effects, but also anti-angiogenic properties. This progress in cancer treatment supports the current focus for development and validation of new biomarkers of angiogenesis in ovarian cancer. In this review, we have outlined some of the key components involved in angiogenesis in ovarian carcinoma. In addition, several of the major angiogenic factors were reviewed as potential markers for disease detection and treatment surveillance in ovarian cancer patients. Although some markers appear to be useful in initial studies, validation in larger prospective trials is required.

\section{Acknowledgments}

William M. Merritt is supported by the National Cancer Institute - DHHS - NIH T32 Training Grant (T32 CA101642-01 A2). Portions of work in this paper were also supported by NIH grants (CA 11079301 and CA 10929801), the U.T.M.D. Anderson Cancer Center SPORE (2P50 CA083639), a Program Project Development Grant from the Ovarian Cancer Research Fund, Inc. and Department of Defense grant \#W81XWH-04$1-0227$ to AKS.

\section{References}

[1] Cancer Facts and Figures 2005, 2005, American Cancer Society: Atlanta.

[2] O. Abulafia, W.E. Triest and D.M. Sherer, Angiogenesis in primary and metastatic epithelial ovarian carcinoma, Am J Obstet Gynecol 177(3) (1997), 541-547.

[3] J. Adams, P.J. Carder, S. Downey, M.A. Forbes, K. MacLennan, V. Allgar, S. Kaufman, S. Hallam, R. Bicknell, J.J. Walker, F. Cairnduff, P.J. Selby, T.J. Perren, M. Lansdown and R.E. Banks, Vascular endothelial growth factor (VEGF) in breast cancer: comparison of plasma, serum, and tissue VEGF and microvessel density and effects of tamoxifen, Cancer Res 60(11) (2000), 2898-2905.

[4] A.A. Alvarez, H.R. Krigman, R.S. Whitaker, R.K. Dodge and G.C. Rodriguez, The prognostic significance of angiogenesis in epithelial ovarian carcinoma, Clin Cancer Res 5(3) (1999), 587-591.

[5] A. Alvarez Secord, R. Sayer, S.A. Snyder, G. Broadwater, G.C. Rodriguez, A. Berchuck and K. Blackwell, The relationship between serum vascular endothelial growth factor, persistent disease, and survival at second-look laparotomy in ovarian cancer, Gynecol Oncol 94(1) (2004), 74-79.

[6] S.M. Apte, D. Fan, J.J. Killion and I.J. Fidler, Targeting the platelet-derived growth factor receptor in antivascular therapy for human ovarian carcinoma, Clin Cancer Res 10(3) (2004), 897-908. 
[7] T. Asahara, H. Masuda, T. Takahashi, C. Kalka, C. Pastore, M. Silver, M. Kearne, M. Magner and J.M. Isner, Bone marrow origin of endothelial progenitor cells responsible for postnatal vasculogenesis in physiological and pathological neovascularization, Circ Res 85(3) (1999), 221-228.

[8] T. Asahara, T. Murohara, A. Sullivan, M. Silver, R. van der Zee, T. Li, B. Witzenbichler, G. Schatteman and J.M. Isner, Isolation of putative progenitor endothelial cells for angiogenesis, Science 275(5302) (1997), 964-967.

[9] T. Asahara, T. Takahashi, H. Masuda, C. Kalka, D. Chen, H. Iwaguro, Y. Inai, M. Silver and J.M. Isner, VEGF contributes to postnatal neovascularization by mobilizing bone marrowderived endothelial progenitor cells, Embo J 18(14) (1999), 3964-3972.

[10] E.S. Bamberger and C.W. Perrett, Angiogenesis in epithelian ovarian cancer, Mol Pathol 55(6) (2002), 348-359.

[11] P. Beaudry, J. Force, G.N. Naumov, A. Wang, C.H. Baker, A. Ryan, S. Soker, B.E. Johnson, J. Folkman and J.V. Heymach, Differential effects of vascular endothelial growth factor receptor-2 inhibitor ZD6474 on circulating endothelial progenitors and mature circulating endothelial cells: implications for use as a surrogate marker of antiangiogenic activity, Clin Cancer Res 11(9) (2005), 3514-3522.

[12] L.V. Beerepoot, N. Mehra, J.S. Vermaat, B.A. Zonnenberg, M.F. Gebbink and E.E. Voest, Increased levels of viable circulating endothelial cells are an indicator of progressive disease in cancer patients, Ann Oncol 15(1) (2004), 139-145.

[13] J.S. Berek, C. Chung, K. Kaldi, J.M. Watson, R.M. Knox and O. Martinez-Maza, Serum interleukin-6 levels correlate with disease status in patients with epithelial ovarian cancer, Am J Obstet Gynecol 164(4) (1991), 1038-1042; discussion 1042-1043.

[14] G. Bergers and L.E. Benjamin, Tumorigenesis and the angiogenic switch, Nat Rev Cancer 3(6) (2003), 401-410.

[15] F. Bertolini, S. Paul, P. Mancuso, S. Monestiroli, A. Gobbi, Y. Shaked and R.S. Kerbel, Maximum tolerable dose and low-dose metronomic chemotherapy have opposite effects on the mobilization and viability of circulating endothelial progenitor cells, Cancer Res 63(15) (2003), 4342-4346.

[16] S. Brem, R. Cotran and J. Folkman, Tumor angiogenesis: a quantitative method for histologic grading, J Natl Cancer Inst 48(2) (1972), 347-356.

[17] C.J. Bruns, M.T. Harbison, D.W. Davis, C.A. Portera, R. Tsan, D.J. McConkey, D.B. Evans, J.L. Abbruzzese, D.J. Hicklin and R. Radinsky, Epidermal growth factor receptor blockade with $\mathrm{C} 225$ plus gemcitabine results in regression of human pancreatic carcinoma growing orthotopically in nude mice by antiangiogenic mechanisms, Clin Cancer Res 6(5) (2000), 1936-1948.

[18] S.A. Cannistra, U. Matulonis, R. Penson, D. Wenham, D. Armstrong, R.A. Burger, H. Mackey, J. Douglas, J. Hambleton and W. McGuire, Bevacizumab in patients with advanced platinum-resistant ovarian cancer, In: Proceedings of the American Society of Clinical Oncology annual meeting (2006).

[19] P. Carmeliet, Mechanisms of angiogenesis and arteriogenesis, Nat Med 6(4) (2000), 389-395.

[20] P. Carmeliet, V. Ferreira, G. Breier, S. Pollefeyt, L. Kieckens, M. Gertsenstein, M. Fahrig, A. Vandenhoeck, K. Harpal, C. Eberhardt, C. Declercq, J. Pawling, L. Moons, D. Collen, W. Risau and A. Nagy, Abnormal blood vessel development and lethality in embryos lacking a single VEGF allele, Nature 380(6573) (1996), 435-439.
[21] J.K. Chan, V. Loizzi, A. Magistris, F. Lin, J. Rutgers, K. Osann, P.J. Disaia, and M.L. Berman, Differences in prognostic molecular markers between women over and under 45 years of age with advanced ovarian cancer, Clin Cancer Res 10(24) (2004), 8538-8543.

[22] B.C. Cooper, J.M. Ritchie, C.L. Broghammer, J. Coffin, J.I. Sorosky, R.E. Buller, M.J. Hendrix and A.K. Sood, Preoperative serum vascular endothelial growth factor levels: significance in ovarian cancer, Clin Cancer Res 8(10) (2002), 3193-3197.

[23] K. Dehaven, D.D. Taylor and C. Gercel-Taylor, Comparison of serum vascular endothelial growth levels between patients with and without ovarian malignancies, Int J Gynecol Cancer 12(6) (2002), 715-719.

[24] F. Demirkiran, B. Kumbak, T. Bese, M. Arvas, A. Benian, S. Aydin, H. Uzun, C. Sanioglu, K. Aydinli and D. Kosebay, Vascular endothelial growth factor in adnexal masses, Int $J$ Gynaecol Obstet 83(1) (2003), 53-58.

[25] H.F. Dvorak, M. Detmar, K.P. Claffey, J.A. Nagy, L. van de Water and D.R. Senger, Vascular permeability factor/vascular endothelial growth factor: an important mediator of angiogenesis in malignancy and inflammation, Int Arch Allergy Immunol 107(1-3) (1995), 233-235.

[26] J.M. Ebos, G. Bocci, S. Man, P.E. Thorpe, D.J. Hicklin, D. Zhou, X. Jia and R.S. Kerbel, A naturally occurring soluble form of vascular endothelial growth factor receptor 2 detected in mouse and human plasma, Mol Cancer Res 2(6) (2004), 315-326.

[27] M. Emoto, H. Iwasaki, M. Ishiguro, M. Kikuchi, S. Horiuchi, T. Saito, N. Tsukamoto and T. Kawarabayashi, Angiogenesis in carcinosarcomas of the uterus: differences in the microvessel density and expression of vascular endothelial growth factor between the epithelial and mesenchymal elements, Hum Pathol 30(10) (1999), 1232-1241.

[28] A. Fasciani, G. D’Ambrogio, G. Bocci, S. Luisi, P.G. Artini and A.R. Genazzani, Vascular endothelial growth factor and interleukin-8 in ovarian cystic pathology, Fertil Steril 75(6) (2001), 1218-1221.

[29] N. Ferrara, The role of VEGF in the regulation of physiological and pathological angiogenesis, Exs 94 (2005), 209-231.

[30] N. Ferrara, H.P. Gerber and J. LeCouter, The biology of VEGF and its receptors, Nat Med 9(6) (2003), 669-676.

[31] S. Ferrero and B.M. Colombo, Differences between plasma and serum vascular endothelial growth factor, Am J Cardiol 98(3) (2006), 424-425.

[32] I.J. Fidler and L.M. Ellis, Chemotherapeutic drugs-more really is not better, Nat Med 6(5) (2000), 500-502.

[33] J. Folkman, How the field of controlled-release technology began, and its central role in the development of angiogenesis research, Biomaterials 11(9) (1990), 615-618.

[34] M.R. Freeman, F.X. Schneck, M.L. Gagnon, C. Corless, S. Soker, K. Niknejad, G.E. Peoples and M. Klagsbrun, Peripheral blood $\mathrm{T}$ lymphocytes and lymphocytes infiltrating human cancers express vascular endothelial growth factor: a potential role for T cells in angiogenesis, Cancer Res 55(18) (1995), 4140-4145.

[35] G. Furstenberger, R. von Moos, R. Lucas, B. Thurlimann, H.J. Senn, J. Hamacher, and E.M. Boneberg, Circulating endothelial cells and angiogenic serum factors during neoadjuvant chemotherapy of primary breast cancer, Br J Cancer 94(4) (2006), 524-531.

[36] H.P. Gerber, A. McMurtrey, J. Kowalski, M. Yan, B.A. Keyt, V. Dixit and N. Ferrara, Vascular endothelial growth factor regulates endothelial cell survival through the phosphatidyli- 
nositol 3'-kinase/Akt signal transduction pathway. Requirement for Flk-1/KDR activation, J Biol Chem 273(46) (1998), 30336-30343.

[37] J. Gille, K. Spieth and R. Kaufmann, Metronomic low-dose chemotherapy as antiangiogenic therapeutic strategy for cancer, J Dtsch Dermatol Ges 3(1) (2005), 26-32.

[38] J.D. Gordon, S. Mesiano, C.J. Zaloudek and R.B. Jaffe, Vascular endothelial growth factor localization in human ovary and fallopian tubes: possible role in reproductive function and ovarian cyst formation, J Clin Endocrinol Metab 81(1) (1996), 353-359.

[39] E. Gorelik, D.P. Landsittel, A.M. Marrangoni, F. Modugno, L. Velikokhatnaya, M.T. Winans, W.L. Bigbee, R.B. Herberman and A.E. Lokshin, Multiplexed immunobead-based cytokine profiling for early detection of ovarian cancer, Cancer Epidemiol Biomarkers Prev 14(4) (2005), 981-987.

[40] S. Grugel, G. Finkenzeller, K. Weindel, B. Barleon and D. Marme, Both v-Ha-Ras and v-Raf stimulate expression of the vascular endothelial growth factor in NIH 3T3 cells, $J$ Biol Chem 270(43) (1995), 25915-25919.

[41] J. Halder, A.A. Kamat, C.N. Landen, L.Y. Han, S.K. Lutgendorf, Y.G. Lin, W.M. Merritt, N.B. Jennings, A. ChavezReyes, R.L. Coleman, D.M. Gershenson, R. Schmandt, S.W. Cole, G. Lopez-Berestein and A.K. Sood, Focal adhesion kinase targeting using in vivo short interfering RNA delivery in neutral liposomes for ovarian carcinoma therapy, Clin Cancer Res 12(16) (2006), 4916-4924.

[42] L.Y. Han, C.N. Landen, J.G. Trevino, A.A. Kamat, T.J. Kim, W.M. Merritt, Y.G. Lin, R.L. Coleman, D.M. Gershenson, W.C. Shakespeare, Y. Wang, R. Sundaramoorth, C.A. Metcalf III, D.C. Dalgamo, T.K. Sawyer, G.E. Gallick and A.K. Sood, Anti-angiogenic and anti-tumor effects of Src inhibition in ovarian carcinoma, Cancer Res 66(17) (2006), 86338639 .

[43] D. Hanahan, G. Bergers and E. Bergsland, Less is more, regularly: metronomic dosing of cytotoxic drugs can target tumor angiogenesis in mice, J Clin Invest 105(8) (2000), 1045-1047.

[44] A. Harlozinska, P. Sedlaczek, J. Kulpa, M. Grybos, E. Wojcik, A. Van Dalen and R. Einarsson, Vascular endothelial growth factor (VEGF) concentration in sera and tumor effusions from patients with ovarian carcinoma, Anticancer Res 24(2C) (2004), 1149-1157.

[45] K. Hattori, B. Heissig, Y. Wu, S. Dias, R. Tejada, B. Ferris, D.J. Hicklin, Z. Zhu, P. Bohlen, L. Witte, J. Hendrikx, N.R. Hackett, R.G. Crystal, M.A. Moore, Z. Werb, D. Lyden and $\mathrm{S}$. Rafii, Placental growth factor reconstitutes hematopoiesis by recruiting VEGFR1(+) stem cells from bone-marrow microenvironment, Nat Med 8(8) (2002), 841-849.

[46] S. Heimburg, M.K. Oehler, T. Papadopoulos, H. Caffier, P. Kristen and J. Dietl, Prognostic relevance of the endothelial marker CD 34 in ovarian cancer, Anticancer Res 19(4A) (1999), 2527-2529.

[47] D.J. Hicklin and L.M. Ellis, Role of the vascular endothelial growth factor pathway in tumor growth and angiogenesis, $J$ Clin Oncol 23(5) (2005), 1011-1027.

[48] S. Hiratsuka, K. Nakamura, S. Iwai, M. Murakami, T. Itoh, H. Kijima, J.M. Shipley, R.M. Senior and M. Shibuya, MMP9 induction by vascular endothelial growth factor receptor-1 is involved in lung-specific metastasis, Cancer Cell 2(4) (2002), 289-300.

[49] J. Holash, P.C. Maisonpierre, D. Compton, P. Boland, C.R. Alexander, D. Zagzag, G.D. Yancopoulos and S.J. Wiegand, Vessel cooption, regression, and growth in tumors mediat- ed by angiopoietins and VEGF, Science 284(5422) (1999), 1994-1998.

[50] H.C. Hollingsworth, E.C. Kohn, S.M. Steinberg, M.L. Rothenberg and M.J. Merino, Tumor angiogenesis in advanced stage ovarian carcinoma, Am J Pathol 147(1) (1995), 33-41.

[51] S. Huang, L. Mills, B. Mian, C. Tellez, M. McCarty, X.D. Yang, J.M. Gudas and M. Bar-Eli, Fully humanized neutralizing antibodies to interleukin-8 (ABX-IL8) inhibit angiogenesis, tumor growth, and metastasis of human melanoma, Am J Pathol 161(1) (2002), 125-134.

[52] H. Hurwitz, L. Fehrenbacher, W. Novotny, T. Cartwright, J. Hainsworth, W. Heim, J. Berlin, A. Baron, S. Griffing, E. Holmgren, N. Ferrara, G. Fyfe, B. Rogers, R. Ross and F. Kabbinavar, Bevacizumab plus irinotecan, fluorouracil, and leucovorin for metastatic colorectal cancer, $N$ Engl J Med 350(23) (2004), 2335-2342.

[53] K. Ivarsson, E. Runesson, K. Sundfeldt, M. Haeger, L. Hedin, P.O. Janson and M. Brannstrom, The chemotactic cytokine interleukin-8-a cyst fluid marker for malignant epithelial ovarian cancer?, Gynecol Oncol 71(3) (1998), 420-423.

[54] R.K. Jain, D.G. Duda, J.W. Clark and J.S. Loeffler, Lessons from phase III clinical trials on anti-VEGF therapy for cancer, Nat Clin Pract Oncol 3(1) (2006), 24-40.

[55] C. Kalka, H. Masuda, T. Takahashi, R. Gordon, O. Tepper, E. Gravereaux, A. Pieczek, H Iwaguro, SI Hayashi, JM Isner, and T Asahara, Vascular endothelial growth factor(165) gene transfer augments circulating endothelial progenitor cells in human subjects, Circ Res 86(12) (2000), 1198-1202.

[56] C. Kalka, H. Tehrani, B. Laudenberg, P.R. Vale, J.M. Isner, T. Asahara and J.F. Symes, VEGF gene transfer mobilizes endothelial progenitor cells in patients with inoperable coronary disease, Ann Thorac Surg 70(3) (2000), 829-834.

[57] A.A. Kamat, T.J. Kim, C.N. Landen, L.Y. Han, W.M. Merritt, D.M. Gershenson and A.K. Sood, Metronomic chemotherapy enhances the efficacy of anti-vascular therapy in ovarian cancer, In: Proceedings of the Society of Gynecologic Oncologists Annual Meeting (2006).

[58] A.A. Kamat and A.K. Sood, The merits of vascular targeting for gynecologic malignancies, Curr Oncol Rep 7(6) (2005), 444-450.

[59] V. Karavasilis, V. Malamou-Mitsi, E. Briasoulis, E. Tsanou, E. Kitsou and N. Pavlidis, Clinicopathologic study of vascular endothelial growth factor, thrombospondin-1, and microvessel density assessed by CD34 in patients with stage III ovarian carcinoma, Int J Gynecol Cancer 16(Suppl 1) (2006), 241-246.

[60] M.J. Karkkainen, T. Makinen and K. Alitalo, Lymphatic endothelium: a new frontier of metastasis research, Nat Cell Biol 4(1) (2002), E2-5.

[61] S.K. Kassim, E.M. El-Salahy, S.T. Fayed, S.A. Helal, T. Helal, D. Azzam Eel and A. Khalifa, Vascular endothelial growth factor and interleukin-8 are associated with poor prognosis in epithelial ovarian cancer patients, Clin Biochem 37(5) (2004), 363-369.

[62] R.L. Kendall and K.A. Thomas, Inhibition of vascular endothelial cell growth factor activity by an endogenously encoded soluble receptor, Proc Natl Acad Sci USA 90(22) (1993), 10705-10709.

[63] F. Kimura, H. Shimizu, H. Yoshidome, M. Ohtsuka, A. Kato, H. Yoshitomi, S. Nozawa, K. Furukawa, N. Mitsuhashi, S. Sawada, D. Takeuchi, S. Ambiru and M. Miyazaki, Circulating cytokines, chemokines, and stress hormones are in- 
creased in patients with organ dysfunction following liver resection, J Surg Res 133(2) (2006), 102-112.

[64] A.E. Koch, P.J. Polverini, S.L. Kunkel, L.A. Harlow, L.A. DiPietro, V.M. Elner, S.G. Elner and R.M. Strieter, Interleukin-8 as a macrophage-derived mediator of angiogenesis, Science 258(5089) (1992), 1798-1801.

[65] C.N. Landen, Jr., A. Chavez-Reyes, C. Bucana, R. Schmandt, M.T. Deavers, G. Lopez-Berestein and A.K. Sood, Therapeutic EphA2 gene targeting in vivo using neutral liposomal small interfering RNA delivery, Cancer Res 65(15) (2005), 6910-6918

[66] C.N. Landen, M.S. Kinch and A.K. Sood, EphA2 as a target for ovarian cancer therapy, Expert Opin Ther Targets 9(6) (2005), 1179-1187.

[67] J.C. Lee, N.H. Chow, S.T. Wang and S.M. Huang, Prognostic value of vascular endothelial growth factor expression in colorectal cancer patients, Eur J Cancer 36(6) (2000), 748753.

[68] L.F. Lee, C.C. Schuerer-Maly, A.K. Lofquist, C. van HaaftenDay, J.P. Ting, C.M. White, B.K. Martin and J.S. Haskill, Taxol-dependent transcriptional activation of IL-8 expression in a subset of human ovarian cancer, Cancer Res 56(6) (1996), 1303-1308

[69] A. Li, S. Dubey, M.L. Varney, B.J. Dave and R.K. Singh, IL-8 directly enhanced endothelial cell survival, proliferation, and matrix metalloproteinases production and regulated angiogenesis, J Immunol 170(6) (2003), 3369-3376.

[70] A. Li, M.L. Varney, J. Valasek, M. Godfrey, B.J. Dave and R.K. Singh, Autocrine role of interleukin-8 in induction of endothelial cell proliferation, survival, migration and MMP2 production and angiogenesis, Angiogenesis 8(1) (2005), 63-71.

[71] L. Li, L. Wang, W. Zhang, B. Tang, J. Zhang, H. Song, D. Yao, Y. Tang, X. Chen, Z. Yang, G. Wang, X. Li, J. Zhao, H. Ding, E. Reed and Q.Q. Li, Correlation of serum VEGF levels with clinical stage, therapy efficacy, tumor metastasis and patient survival in ovarian cancer, Anticancer Res 24(3b) (2004), 1973-1939.

[72] Q.J. Li, M. Yao, W. Wong, V. Parpura and M. Martins-Green, The N- and C-terminal peptides of hIL8/CXCL8 are ligands for hCXCR1 and hCXCR2, Faseb J 18(6) (2004), 776-778.

[73] Y.G. Lin, A.A. Kamat, L.Y. Han, W.M. Merritt, P.H. Thaker, C.N. Landen, Jr., M.T. Deavers, M.S. Fletcher, D.M. Gershenson, R.L. Coleman, M.S. Kinch and A.K. Sood, EphA2 overexpression is associated with angiogenesis in ovarian carcinoma, In: Proceedings of the American Association for Cancer Research annual meeting (2006).

[74] L.A. Liotta, J. Kleinerman and G.M. Saidel, Quantitative relationships of intravascular tumor cells, tumor vessels, and pulmonary metastases following tumor implantation, Cancer Res 34(5) (1974), 997-1004.

[75] A.E. Lokshin, M. Winans, D. Landsittel, A.M. Marrangoni, L. Velikokhatnaya, F. Modugno, B.M. Nolen and E. Gorelik, Circulating IL-8 and anti-IL-8 autoantibody in patients with ovarian cancer, Gynecol Oncol (2006).

[76] D. Lyden, K. Hattori, S. Dias, C. Costa, P. Blaikie, L. Butros, A. Chadburn, B. Heissig, W. Marks, L. Witte, Y. Wu, D. Hicklin, Z. Zhu, N.R. Hackett, R.G. Crystal, M.A. Moore, K.A. Hajjar, K. Manova, R. Benezra and S. Rafii, Impaired recruitment of bone-marrow-derived endothelial and hematopoietic precursor cells blocks tumor angiogenesis and growth, Nat Med 7(11) (2001), 1194-1201.
[77] S. Malik and F. Balkwill, Epithelial ovarian cancer: a cytokine propelled disease? Br J Cancer 64(4) (1991), 617620.

[78] P. Mancuso, A. Burlini, G. Pruneri, A. Goldhirsch, G. Martinelli and F. Bertolini, Resting and activated endothelial cells are increased in the peripheral blood of cancer patients, Blood 97(11) (2001), 3658-3661.

[79] A.J. Maniotis, R. Folberg, A. Hess, E.A. Seftor, L.M. Gardner, J. Pe'er, J.M. Trent, P.S. Meltzer and M.J. Hendrix, Vascular channel formation by human melanoma cells in vivo and in vitro: vasculogenic mimicry, Am J Pathol 155(3) (1999), 739-752.

[80] K. Mayerhofer, K. Bodner, B. Bodner-Adler, M. Schindl, A. Kaider, L. Hefler, R. Zeillinger, S. Leodolter, E.A. Joura and C. Kainz, Interleukin-8 serum level shift in patients with ovarian carcinoma undergoing paclitaxel-containing chemotherapy, Cancer 91(2) (2001), 388-393.

[81] B. Millauer, S. Wizigmann-Voos, H. Schnurch, R. Martinez, N.P. Moller, W. Risau and A. Ullrich, High affinity VEGF binding and developmental expression suggest Flk-1 as a major regulator of vasculogenesis and angiogenesis, Cell 72(6) (1993), 835-846.

[82] S. Monestiroli, P. Mancuso, A. Burlini, G. Pruneri, C. Dell'Agnola, A. Gobbi, G. Martinelli and F. Bertolini, Kinetics and viability of circulating endothelial cells as surrogate angiogenesis marker in an animal model of human lymphoma, Cancer Res 61(11) (2001), 4341-4344.

[83] R.J. Motzer, M.D. Michaelson, B.G. Redman, G.R. Hudes, G. Wilding, R.A. Figlin, M.S. Ginsberg, S.T. Kim, C.M. Baum, S.E. DePrimo, J.Z. Li, C.L. Bello, C.P. Theuer, D.J. George and B.I. Rini, Activity of SU11248, a multitargeted inhibitor of vascular endothelial growth factor receptor and platelet-derived growth factor receptor, in patients with metastatic renal cell carcinoma, J Clin Oncol 24(1) (2006), 16-24.

[84] G. Neufeld, T. Cohen, S. Gengrinovitch and Z. Poltorak, Vascular endothelial growth factor (VEGF) and its receptors, Faseb J 13(1) (1999), 9-22.

[85] M.B. Nilsson, R.R. Langley and I.J. Fidler, Interleukin-6, secreted by human ovarian carcinoma cells, is a potent proangiogenic cytokine, Cancer Res 65(23) (2005), 10794-10800.

[86] J.E. Nor, J. Christensen, D.J. Mooney and P.J. Polverini, Vascular endothelial growth factor (VEGF)-mediated angiogenesis is associated with enhanced endothelial cell survival and induction of Bcl-2 expression, Am J Pathol 154(2) (1999), 375-384.

[87] J.E. Nor, R.S. Mitra, M.M. Sutorik, D.J. Mooney, V.P. Castle and P.J. Polverini, Thrombospondin-1 induces endothelial cell apoptosis and inhibits angiogenesis by activating the caspase death pathway, J Vasc Res 37(3) (2000), 209-218.

[88] M. Nowak, M. Szpakowski, A. Malinowski, A. Wieczorek, G. Maciolek-Blewniewska, J.R. Wilczynski, A. Szpakowski, E. Wierzbicka, E. Malafiej and P. Oszukowski, [Serum cytokines in patients with ovarian cancer and benign ovarian cysts], Ginekol Pol 72(12A) (2001), 1444-1448.

[89] A. Obermair, C. Tempfer, L. Hefler, O. Preyer, A. Kaider, R. Zeillinger, S. Leodolter and C. Kainz, Concentration of vascular endothelial growth factor (VEGF) in the serum of patients with suspected ovarian cancer, Br J Cancer 77(11) (1998), 1870-1874.

[90] A. Obermair, R. Wasicky, A. Kaider, O. Preyer, A. Losch, S. Leodolter and H. Kolbl, Prognostic significance of tumor angiogenesis in epithelial ovarian cancer, Cancer Lett 138(12) (1999), 175-182. 
[91] M.K. Oehler and H. Caffier, Prognostic relevance of serum vascular endothelial growth factor in ovarian cancer, Anticancer Res 20(6D) (2000), 5109-5112.

[92] M.K. Oehler and H. Caffier, Diagnostic value of serum VEGF in women with ovarian tumors, Anticancer Res 19(4A) (1999), 2519-2522.

[93] P.J. Paley, K.A. Staskus, K. Gebhard, D. Mohanraj, L.B. Twiggs, L.F. Carson and S. Ramakrishnan, Vascular endothelial growth factor expression in early stage ovarian carcinoma, Cancer 80(1) (1997), 98-106.

[94] H.M. Pinedo, H.M. Verheul, R.J. D'Amato and J. Folkman, Involvement of platelets in tumour angiogenesis?, Lancet 352(9142) (1998), 1775-1777.

[95] M. Plante, S.C. Rubin, G.Y. Wong, M.G. Federici, C.L. Finstad and G.A. Gastl, Interleukin-6 level in serum and ascites as a prognostic factor in patients with epithelial ovarian cancer, Cancer 73(7) (1994), 1882-1888.

[96] R.T. Poon, S.T. Fan and J. Wong, Clinical implications of circulating angiogenic factors in cancer patients, J Clin Oncol 19(4) (2001), 1207-1225.

[97] I. Rajantie, M. Ilmonen, A. Alminaite, U. Ozerdem, K. Alitalo and P. Salven, Adult bone marrow-derived cells recruited during angiogenesis comprise precursors for periendothelial vascular mural cells, Blood 104(7) (2004), 2084-2086.

[98] M.R. Raspollini, G. Amunni, A. Villanucci, G. Baroni, V. Boddi, D. Rossi Degl'innocenti and G.L. Taddei, Microvessel density in ovarian carcinoma: computer image analysis in patients with shorter and longer survival, Int $J$ Gynecol Cancer 15(5) (2005), 844-849.

[99] M.R. Raspollini, G. Amunni, A. Villanucci, V. Boddi, G. Baroni, A. Taddei and G.L. Taddei, COX-2 status in relation to tumor microvessel density and VEGF expression: analysis in ovarian carcinoma patients with low versus high survival rates, Oncol Rep 11(2) (2004), 309-313.

[100] W. Risau, Mechanisms of angiogenesis, Nature 386(6626) (1997), 671-674.

[101] D.G. Rosen, L. Wang, J.N. Atkinson, Y. Yu, K.H. Lu, E.P. Diamandis, I. Hellstrom, S.C. Mok, J. Liu and R.C. Bast, Jr., Potential markers that complement expression of CA125 in epithelial ovarian cancer, Gynecol Oncol 99(2) (2005), 267-277.

[102] W.M. Schoell, D. Pieber, O. Reich, M. Lahousen, M. Janicek, F. Guecer and R. Winter, Tumor angiogenesis as a prognostic factor in ovarian carcinoma: quantification of endothelial immunoreactivity by image analysis, Cancer 80(12) (1997), 2257-2262.

[103] D.R. Senger, L. Van de Water, L.F. Brown, J.A. Nagy, K.T. Yeo, T.K. Yeo, B. Berse, R.W. Jackman, A.M. Dvorak and H.F. Dvorak, Vascular permeability factor (VPF, VEGF) in tumor biology, Cancer Metastasis Rev 12(3-4) (1993), 303324.

[104] F. Shalaby, J. Rossant, T.P. Yamaguchi, M. Gertsenstein, X.F. Wu, M.L. Breitman and A.C. Schuh, Failure of blood-island formation and vasculogenesis in Flk-1-deficient mice, Nature 376(6535) (1995), 62-66

[105] K. Shirakawa, H. Wakasugi, Y. Heike, I. Watanabe, S. Yamada, K. Saito and F. Konishi, Vasculogenic mimicry and pseudo-comedo formation in breast cancer, Int $J$ Cancer 99(6) (2002), 821-828.

[106] A.K. Sood, M.S. Fletcher, C.M. Zahn, L.M. Gruman, J.E. Coffin, E.A. Seftor and M.J. Hendrix, The clinical significance of tumor cell-lined vasculature in ovarian carcinoma: implications for anti-vasculogenic therapy, Cancer Biol Ther 1(6) (2002), 661-664.
[107] A.K. Sood, E.A. Seftor, M.S. Fletcher, L.M. Gardner, P.M. Heidger, R.E. Buller, R.E. Seftor and M.J. Hendrix, Molecular determinants of ovarian cancer plasticity, Am J Pathol 158(4) (2001), 1279-1288.

[108] P.J. Stone, M.J. Goodheart, S.L. Rose, B.J. Smith, B.R. DeYoung and R.E. Buller, The influence of microvessel density on ovarian carcinogenesis, Gynecol Oncol 90(3) (2003), 566-571.

[109] J.M. Summy, J.G. Trevino, D.P. Lesslie, C.H. Baker, W.C. Shakespeare, Y. Wang, R. Sundaramoorthi, C.A. Metcalf, 3rd, J.A. Keats, T.K. Sawyer and G.E. Gallick, AP23846, a novel and highly potent Src family kinase inhibitor, reduces vascular endothelial growth factor and interleukin-8 expression in human solid tumor cell lines and abrogates downstream angiogenic processes, Mol Cancer Ther 4(12) (2005), 1900-1911

[110] H.M. Tanir, S. Ozalp, O.T. Yalcin, O. Colak, A. Akcay and T. Senses, Preoperative serum vascular endothelial growth factor (VEGF) in ovarian masses, Eur J Gynaecol Oncol 24(3-4) (2003), 271-274.

[111] C. Tempfer, H. Zeisler, G. Sliutz, G. Haeusler, E. Hanzal and C. Kainz, Serum evaluation of interleukin 6 in ovarian cancer patients, Gynecol Oncol 66(1) (1997), 27-30.

[112] P.H. Thaker, S. Yazici, M.B. Nilsson, K. Yokoi, R.Z. Tsan, J. He, S.J. Kim, I.J. Fidler and A.K. Sood, Antivascular therapy for orthotopic human ovarian carcinoma through blockade of the vascular endothelial growth factor and epidermal growth factor receptors, Clin Cancer Res 11(13) (2005), 4923-4933.

[113] M. Toi, T. Tominaga, A. Osaki and T. Toge, Role of epidermal growth factor receptor expression in primary breast cancer: results of a biochemical study and an immunocytochemical study, Breast Cancer Res Treat 29(1) (1994), 51-58.

[114] M. Ueda, Y.C. Hung, Y. Terai, K. Kanda, M. Kanemura, H. Futakuchi, H. Yamaguchi, D. Akise, M. Yasuda and M. Ueki, Vascular endothelial growth factor-C expression and invasive phenotype in ovarian carcinomas, Clin Cancer Res 11(9) (2005), 3225-3232.

[115] R. Uslu, U.A. Sanli, Y. Dikmen, B. Karabulut, A. Ozsaran, C. Sezgin, G.G. Muezzinoglu, S.B. Omay and E. Goker, Predictive value of serum interleukin- 8 levels in ovarian cancer patients treated with paclitaxel-containing regimens, Int J Gynecol Cancer 15(2) (2005), 240-245.

[116] U. Wartiovaara, P. Salven, H. Mikkola, R. Lassila, J. Kaukonen, V. Joukov, A. Orpana, A. Ristimaki, M. Heikinheimo, H. Joensuu, K. Alitalo and A. Palotie, Peripheral blood platelets express VEGF-C and VEGF which are released during platelet activation, Thromb Haemost 80(1) (1998), 171175 .

[117] N.J. Webb, M.J. Bottomley, C.J. Watson and P.E. Brenchley, Vascular endothelial growth factor (VEGF) is released from platelets during blood clotting: implications for measurement of circulating VEGF levels in clinical disease, Clin Sci (Lond) 94(4) (1998), 395-404.

[118] N. Weidner and J. Folkman, Tumoral vascularity as a prognostic factor in cancer, Important Adv Oncol (1996), 167190.

[119] C.G. Willett, Y. Boucher, D.G. Duda, E. di Tomaso, L.L. Munn, R.T. Tong, S.V. Kozin, L. Petit, R.K. Jain, D.C. Chung, D.V. Sahani, S.P. Kalva, K.S. Cohen, D.T. Scadden, A.J. Fischman, J.W. Clark, D.P. Ryan, A.X. Zhu, L.S. Blaszkowsky, P.C. Shellito, M. Mino-Kenudson and G.Y. Lauwers, Surrogate markers for antiangiogenic therapy and dose-limiting toxicities for bevacizumab with radiation and chemothera- 
py: continued experience of a phase I trial in rectal cancer patients, J Clin Oncol 23(31) (2005), 8136-8139.

[120] C. Wulff, H. Wilson, J.S. Rudge, S.J. Wiegand, S.F. Lunn and H.M. Fraser, Luteal angiogenesis: prevention and intervention by treatment with vascular endothelial growth factor trap(A40), J Clin Endocrinol Metab 86(7) (2001), 33773386.

[121] S. Yamamoto, I. Konishi, M. Mandai, H. Kuroda, T. Komatsu, K. Nanbu, H. Sakahara and T. Mori, Expression of vascular endothelial growth factor (VEGF) in epithelial ovarian neoplasms: correlation with clinicopathology and patient survival, and analysis of serum VEGF levels, Br J Cancer 76(9) (1997), 1221-1227.
[122] A. Yuan, C.J. Yu, K.T. Luh, S.H. Kuo, Y.C. Lee and P.C. Yang, Aberrant p53 expression correlates with expression of vascular endothelial growth factor mRNA and interleukin-8 mRNA and neoangiogenesis in non-small-cell lung cancer, $J$ Clin Oncol 20(4) (2002), 900-910.

[123] H. Zeng, H.F. Dvorak and D. Mukhopadhyay, Vascular permeability factor (VPF)/vascular endothelial growth factor (VEGF) peceptor-1 down-modulates VPF/VEGF receptor2-mediated endothelial cell proliferation, but not migration, through phosphatidylinositol 3-kinase-dependent pathways, J Biol Chem 276(29) (2001), 26969-26979. 


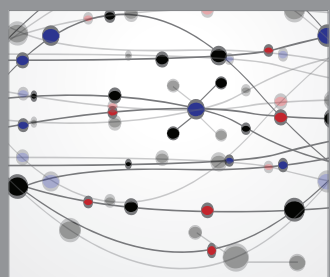

The Scientific World Journal
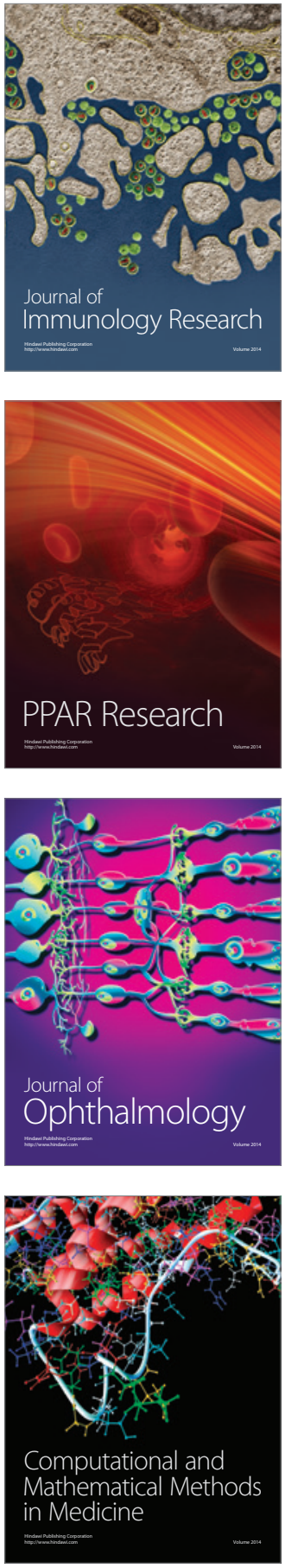

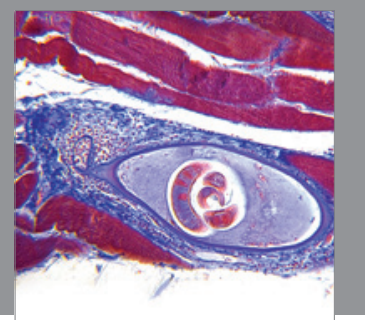

Gastroenterology

Research and Practice
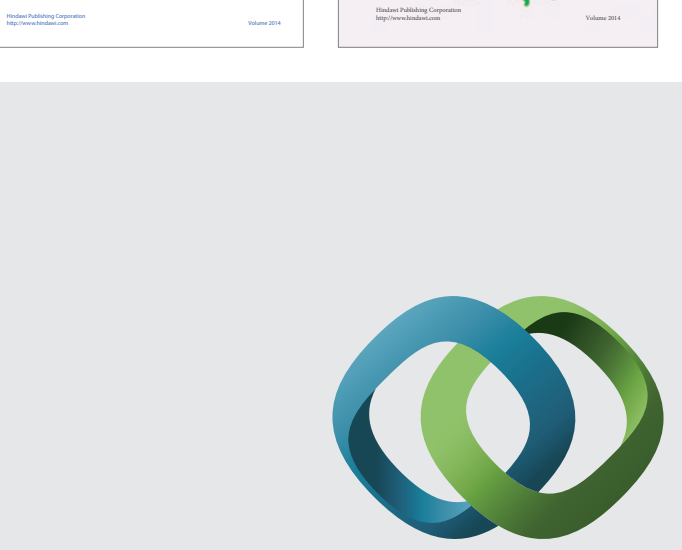

\section{Hindawi}

Submit your manuscripts at

http://www.hindawi.com
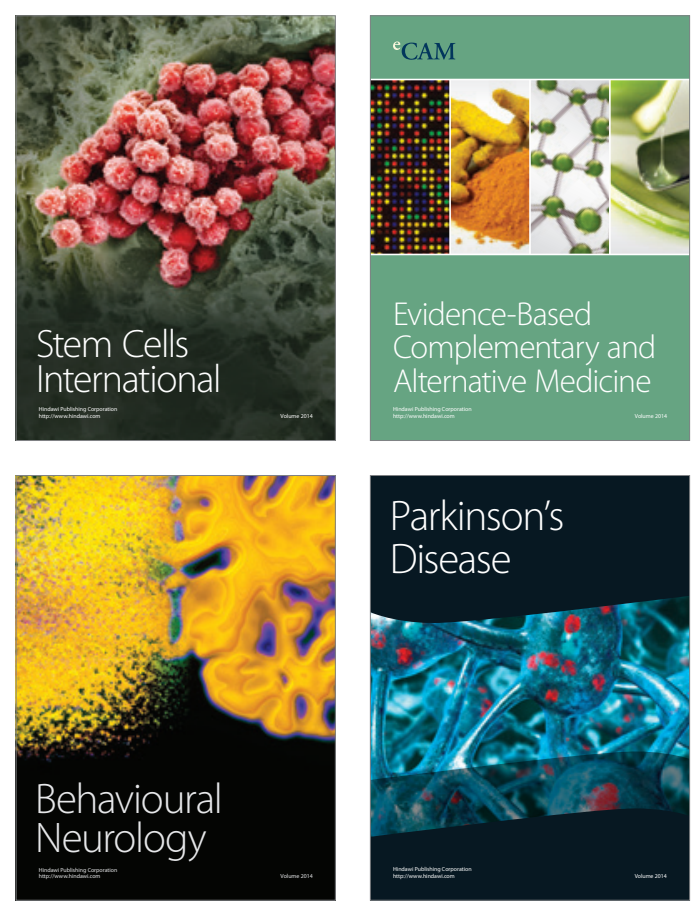

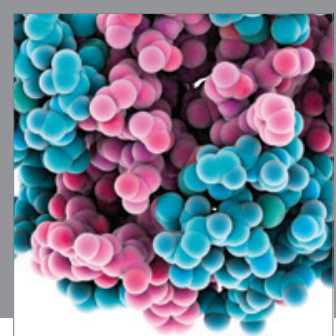

Journal of
Diabetes Research

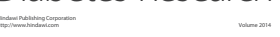

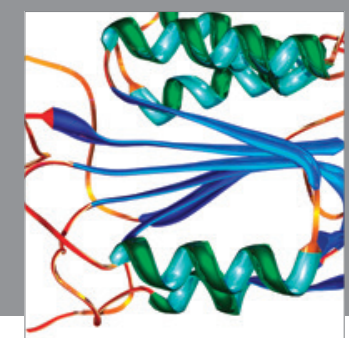

Disease Markers
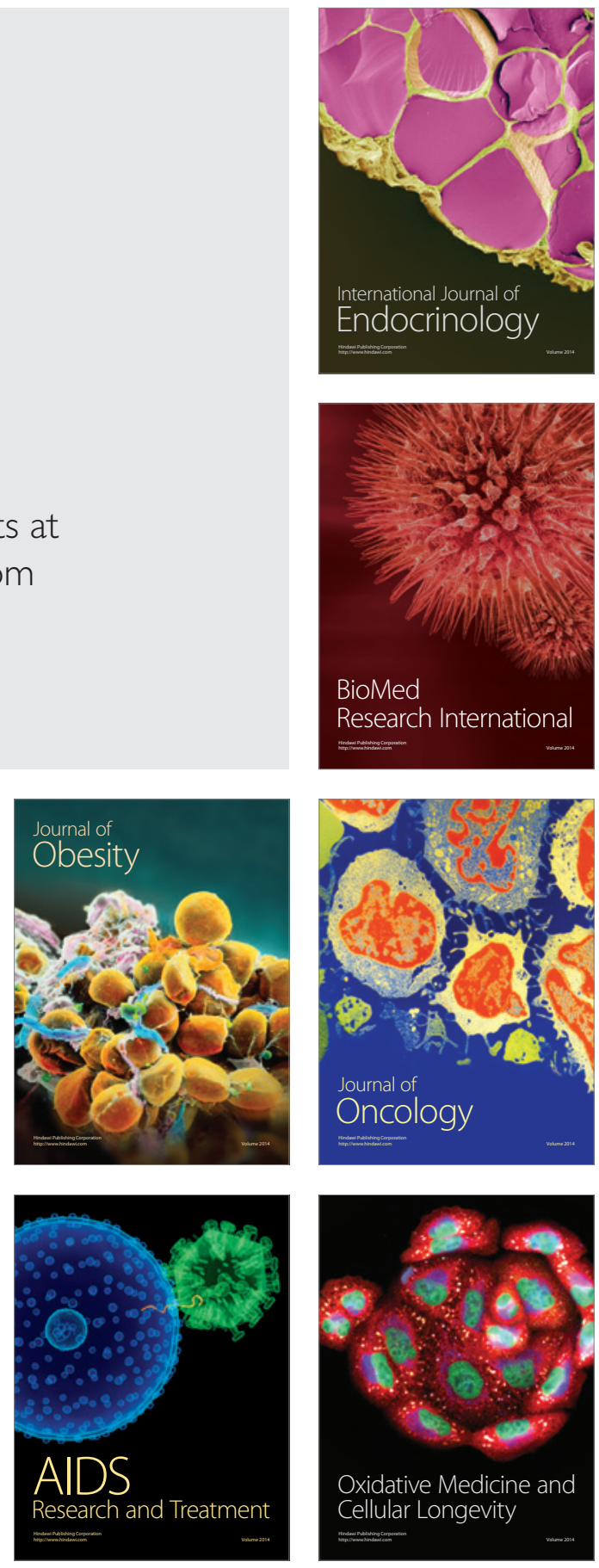